\title{
Article \\ Cash Holding and Firm Value in the Presence of Managerial Optimism
}

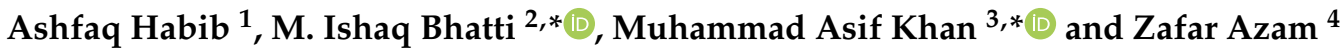 \\ 1 Department of Commerce, University of Poonch Rawalakot, Rawalakot 12350, Azad Jammu and Kashmir, \\ Pakistan; ashfaqhabib@upr.edu.pk \\ 2 La Trobe Business School, La Trobe University, Melbourne 3086, Australia \\ 3 Department of Commerce, Faculty of Management Sciences, University of Kotli, Kotli 11100, \\ Azad Jammu and Kashmir, Pakistan \\ 4 Department of Business Administration, University of Poonch Rawalakot 12350, Rawalakot 12350, \\ Azad Jammu and Kashmir, Pakistan; zafarazam@upr.edu.pk \\ * Correspondence: I.Bhatti@latrobe.edu.au (M.I.B.); khanasif82@uokajk.edu.pk (M.A.K.)
}

check for updates

Citation: Habib, Ashfaq, M. Ishaq Bhatti, Muhammad Asif Khan, and Zafar Azam. 2021. Cash Holding and Firm Value in the Presence of Managerial Optimism. Journal of Risk and Financial Management 14: 356. https://doi.org/10.3390/jrfm14080356

Academic Editor: Goran Buturac

Received: 21 June 2021

Accepted: 15 July 2021

Published: 4 August 2021

Publisher's Note: MDPI stays neutral with regard to jurisdictional claims in published maps and institutional affiliations.

Copyright: (c) 2021 by the authors. Licensee MDPI, Basel, Switzerland. This article is an open access article distributed under the terms and conditions of the Creative Commons Attribution (CC BY) license (https:/ / creativecommons.org/licenses/by/ $4.0 /)$

\begin{abstract}
Cash holding is important for Chinese manufacturing firms coping with the increasing costs of financing and tough economic conditions. This study examines the impact of cash holding on the firm value of Chinese manufacturing businesses. We found evidence that a non-linear relationship exists between cash holding and firm value in these companies. The study reveals that a higher level of cash holding in financially constrained firms negatively affects the firm value, while unconstrained firms with a less cash holding level have a better firm value. Finally, this research is enriched by implementing the novel measure of managerial optimism. Revealed is the interactive role of cash holding and optimism and how they affect firm value. The study concludes that managerial optimism influences a firm's cash holding decisions, and this is more costly for unconstrained firms.
\end{abstract}

Keywords: cash holding; firm value; managerial optimism; financial constraint

\section{Introduction}

The increasing trend of corporate cash reserves has attracted the attention of researchers and policy-holders in recent times. Nearly twenty years ago, Dittmar et al. (2003) identified the existence of US\$1.5 trillion cash reserves in the world's largest organizations at the end of 1998. In their analysis, Bates et al. (2009) recognized the US\$2.80 trillion cash reserves in the world's top 1000 non-financial corporations. Likewise, Opler et al. (1999) documented US\$1.5 trillion cash reserves in Standard \& Poor's 500 companies. Again, referring to Bates et al. (2009), they identified cash holding reserves increased by $46 \%$ per annum from 1980 to 2006 in U.S. firms. China is now a major provider of liquidity in the global market (see Do et al. 2020). Since 1996, the M2 of China has surpassed by 75\% of the M2 provided by the U.S., Europe, and Japan. In 2009, China's M2 as measured in U.S. dollars surpassed that of the U.S. for the first time (Caldentey 2017).

Cash holding is indeed important for Chinese firms, which until the COVID-19 outbreak was the world's fastest-growing economy, but this concept also reveals the underdeveloped financial system where firms face obstacles in raising funds externally. In contrast to Western countries, the Chinese financial system is less developed and subject to pronounced agency problems and asymmetric information (Heyman et al. 2003; Morck et al. 2005; Vijayakumaran 2017). Cash retention by Chinese firms has attained a lot of scholarly and business attention. For example, Su et al. (2020) noted that Chinese listed companies retained large cash reserves from 1998 to 2001. Similarly, Pinkowitz et al. (2004) documented that Chinese companies' cash-to-assets ratio was 18.9\% during 2000-2003. During this time, U.S. and UK companies' cash-to-assets ratios amounted to $8.1 \%$ and 9.90\%, respectively (Ozkan and Ozkan 2004). 
The self-financing growth of Chinese firms was 17.8\% from 1994 to 2006, and in 2006, it reached 665.6 billion, which was almost double the local bank financing (Allen et al. 2007). Likewise, Zhu and Lu (2009) reported that the average cash holding in China was $24 \%$ from 1998 to 2007, which was higher than that for U.S. companies during that period. Moreover, the Chinese firms managed the informal credit granted by their vendors (banks and/or other financial institutions) to finance growth opportunities (Liu et al. 2020). Further, Ding et al. (2013) revealed that Chinese firms retain the funds from their operations, use bank financing and trade credit to finance their business operations (Hu et al. 2016). Fang et al. (2015) noted that Chinese firms retain more cash to finance business operations due to the unpredictable long-term capital market. The lower cost of internal financing enhances the ability of Chinese firms to invest more.

In theory, firms maintain cash for productivity purposes or increase returns to shareholders. Internal cash holding provides a low-cost financing option for firms (Subramaniam et al. 2011). Keynes and Waeger (1936) argue that internal cash holding reduces the transaction costs of cash holding to readily make funds available for business reasons. The firms also maintain cash to meet unexpected situations in the future or to finance new investment projects or transactions. Likewise, Harford (1999) states that firms having substantial growth opportunities and high uncertainty of future cash flows will retain more cash.

Conversely, the excess cash balance increases the opportunity cost of cash holding, such as a lower rate of return on liquidity investment and double taxation which negatively affect the firms' value (Jugurnath et al. 2008). Additionally, Faulkender and Wang (2006) explain that additional benefits of cash holding decline with rising levels of cash holding. In their work, Humphery-Jenner and Powell (2011) suggest that cash-rich companies perform worse than the average industry if they consistently hold cash instead of distributing it to shareholders. The firms want to maintain the best possible cash holding level, where the cost involved is compensated for by cash holding benefits (Nguyen Thanh 2019). Martínez-Sola et al. (2013) explain that managers essentially want the best cash holding level to increase the firm's value and any deviation from it will do damage to the firm value. Moreover, these same authors identify the desired cash holding level by investigating the nonlinear relationship between cash holding and firm value.

The trade-off theory sets the optimal cash holding level by balancing the marginal benefits and cost of holding (Kraus and Litzenberger 1973). However, the ordering hypothesis suggests that marginal benefits can be maximized by using internal financing (Myers and Majluf 1984). Internal cash flows reduce the agency cost between the capital providers and managers (Hill and Jones 1992). They also reduce the pressure wrought by external capital providers on managers who seek to look to their own interests and not those of shareholders (Jensen 1986). Therefore, firms' marginal benefits of cash holding decrease with higher internal cash holding, and managers choose projects that reflect their own interests but not those providing the funds. It leads to our first research question: does the higher cash holding negatively affect firm value, and does lower cash holding positively influence firm value?

However, what about firms that do not have a sufficient amount of internal cash flows but still have an opportunity to raise funds externally at a reasonable cost? Such firms have lower leverage and can adopt external debt financing at a lower cost to invest in potentially profitable NPV projects. Myers and Majluf (1984) contend that such firms choose debt financing to procure the investment opportunity, but additional debt financing reduces the marginal benefits of cash holding and leads to external capital providers putting pressure on firms' investment decisions. Thus, reducing the level of marginal benefits of cash holding and external capital provider pressure forces managers to only invest in viable NPV projects. It raises our second research question: do the lower level of cash holding and the opportunity to raise finance externally at a reasonable cost positively influence firm value? 
Recent studies on corporate finance have highlighted the influence of managers' optimism in decisions made about cash holdings. Optimism is a behavioral bias that is widely discussed in the context of managers' psychological beliefs and motivations. Nofsinger and Wang (2011) empirically state the managerial behavioral biases tied up with corporate finance and explain that these biases influence how decisions are arrived at. Optimistic managers are always forecasting positive outcomes and better future performance. They are confident and presume that under their direction all the required work will be accomplished and generate a superior return than the actual return (Tran et al. 2020). Optimists are convinced that overestimating the return of well-performed firms is justified and assume that the market undervalues their securities. They believe that the issuance of new equity is costly and a firm prefers debt financing, once internally generated funds have been spent (Huang-Meier et al. 2016; Stephens et al. 2007). In reality, this generates agency and asymmetric problems.

Mohamed et al. (2014) explain that a firm's cash flow volatility increases due to overly optimistic managers. Similarly, Mohamed et al. (2020) explain that optimistic managers are motivated to invest more with internal financing. This is because optimists are confident that external financing is more expensive than internal cash flows. Mohamed and Shehata (2020) explain that optimists are even unwilling to invest in profitable projects with smaller internal cash balances. Conversely, optimistic managers are willing to invest more with plenty of internal cash flows and forecast higher future returns, which can lead to investment in overestimated projects (negative NPV) that do not generate an appropriate cash flow to offset the financing cost. It raises our third research question: does managerial optimism in financially unconstrained firms enhance the negative effect of cash holding on firm value, but for cash-constrained firms positively?

When the firms do not have adequate internal cash holding and yet are in a position to generate finance externally, then optimistic managers may take the opportunity of debt financing. However, optimistic managers overestimate the future return and may invest in risky NPV projects. Here, our fourth research question emerges: if a firm has an optimistic manager, does a lower level of cash holding the opportunity to raise finance externally negatively affect firm value? Therefore, this study contributes to the current literature on this topic in various ways. Firstly, it investigates the impact of a non-linear relationship of cash holding on firm value in Chinese manufacturing companies. Secondly, it develops a unique classification scheme to segregate financially constrained and unconstrained firms to reveal the impact of cash holding on firm value in these firms. Thirdly, it contributes by developing a novel technique of earnings forecast errors to measure managerial optimism, in an effort to explain the impact of cash holding on firm value when managerial optimism is evident. To this end, the purpose of this study is to examine the effect of cash holdings on firm value in financially constrained and unconstrained firms. The structure of the rest of this paper is as follows. In the next section, we review important aspects of the literature and research methodologies being used in this area. It also contains the development of our hypothesis in line with the research question. Section 3 contains the selection of the sample being used, the data set, and the choice of research methodology, whereas Section 4 is allocated to the explanation of the results obtained and some important discussions. The final section contains some concluding remarks with reference to managerial and policy implications.

\section{Literature Review}

\subsection{Cash Holding and Financial Constraints}

Corporate cash holding has increased worldwide in recent decades and garnered the attention of investors and researchers. Several research studies examined the sensitivity and consequences of large cash holdings that companies have (Lins et al. 2010; Bates et al. 2009; Han and Qiu 2007). Opler et al. (1999) argue that firms maintain cash for transaction reasons and this is a precautionary move to fulfill unforeseen needs particularly when external financing is costly. Orr and Miller (1966) state that any factors that undermine the 
consistency of cash flows from business operations may encourage businesses to maintain a target level of cash as insurance against the risk of uncertainty for future cash flows.

A plethora of research recognizes that firms retain cash to run their routines and procedures and save it for investment purposes (Adrian et al. 2012; Baum et al. 2008; Dae Mello et al. 2008; Dittmar et al. 2003). Almeida et al. (2004) did empirical investigation and found that financially constrained firms hold more cash than unconstrained firms due to the profitable opportunities inherent in this strategy. Similarly, Khatami et al. (2015) revealed that cash holding in constrained firms can overcome the underinvestment problem. Denis and Sibilkov (2010) contend that internal cash holding and capacity to finance externally are important measures of financial constraints. The firm's internal cash holding is a major source of financing and liquidity for constrained firms. In their research, Edwards et al. (2016) documented that tax-saving practices are implemented in constrained firms by retaining the cash to finance viable projects.

Kim et al. (2011) analyzed cash holding levels in U.S. firms. Their study noted that financially constrained firms retain excess cash to reduce the costs of external financing and the expected higher uncertainty of future cash flows. Similarly, Opler et al. (1999) revealed that firms with growth opportunities but fluctuating cash flows prefer to hold excess cash. Likewise, Bigelli and Sánchez-Vidal (2012) found a cash holding pattern in Italian public and private sector firms. Their study found that cash holding is higher in the public sector firms due to the uncertainty of future cash flows and how or if the tax rate may change. Gao et al. (2013) point out the higher agency cost of capital, while Asker et al. (2015) target the asymmetry problem as influencing the firm's desire to hold more cash.

On the other hand, Harford (1999) explain that cash holding convinces managers to invest in lower value mergers and acquisitions. Faulkender and Wang (2006) discover that higher cash holding firms have a lower value when the level of debt increases because value generated by cash may serve to pay debt holders rather than shareholders. Dittmar et al. (2003) found that managers use internal cash holding as a way to invest in a project that best suits their interests rather than those of shareholders. In their older study, Opler et al. (1999) investigated that managers may use internal cash holding to increase control on firms rather than pay a dividend to shareholders. Isshaq et al. (2009) reveal that higher cash holding and rarer investment opportunities may diminish the value of firms because excess cash holding forces managers to overinvest. Firms reduce the agency cost of capital and overinvestment problems by distributing excess cash among shareholders (Easterbrook 1984; Jensen 1986; Dittmar et al. 2003). In their study, Faulkender and Wang (2006) show that the additional benefits of cash decrease when the amount of cash held increases.

Therefore, financially constrained firms hold cash to reduce any risk of liquidity shortage and expensive external financing. These firms also retain cash to realize profitable opportunities without resorting to costly external financing. However, higher cash holding increases the financing and opportunity cost of capital. It also promotes the agency cost of capital, which negatively influences firm value. In contrast, financially unconstrained firms do not need to hold more cash, because they can generate the required cash flows from their operations well enough. Unconstrained firms have stable cash flows and can finance externally at a reasonable cost. Less cash holding in unconstrained firms reduces, firstly the financing and opportunity cost of capital and secondly the firm agency and asymmetric cost of capital. On this basis, we propose the hypotheses:

Hypothesis 1. The firm's internal cash holding develops a nonlinear relationship with firm value.

Hypothesis 2. A higher cash holding level in financially constrained firms may negatively influence firm value.

Hypothesis 3. A lower cash holding level in financially unconstrained firms may positively influence firm value. 


\subsection{Managerial Optimism and Cash Holding}

Corporate managers are considered rational when they make capital budgeting decisions, and the circumstances around cash holding are also assumed to be unaffected by the personal traits of managers. Contrarily, behavioral finance studies find that managers' traits do affect financing decisions. Heaton (2002) predict that managerial optimism influences financial and investment policies carried out in firms. Optimistic managers overestimate projects under their supervision and underestimate the uncertainty of outcomes. Further, Campello and Hackbarth (2008), Mohamed et al. (2014), Agarwal et al. (2015), and Campello and Graham (2013) explain that managerial optimism plays an essential role in determining the long-term financing and investment policies of companies.

Mohamed et al. (2014) explain that optimistic managers invest more using internal funds and are reluctant to find external sources of finance. Recently, Huang-Meier et al. (2016) and Deshmukh et al. (2021) argue that optimistic managers prefer to retain cash for investment by paying smaller dividends to shareholders. Such managers forecast the higher return from announced projects and desire to hoard cash for investment opportunities. Similarly, Puri and Robinson (2007) find that optimistic managers may overinvest by overvaluing the cash flows of projects and underinvestment arises when the internal cash holding is smaller. Further, Chen and Lin (2012) explain that optimists think the stock market undervalues their security prices, resulting in expensive external financing. In such conditions, optimists use internal cash holding for investment and reduce external financing. Conversely, Wang et al. (2020) propose two opposite aspects of managerial optimism and firm cash holding. Firstly, in constrained firms, optimists retain more cash than rational managers for growth opportunities and avoid external financing. Secondly, in unconstrained firms, optimistic managers invest more, and their cash usage is higher than what rational managers do.

Chen and Lin (2012) found that optimistic managers in financially constrained firms ignore potentially profitable NPV projects due to issues around lower internal cash holding and costly external financing. Likewise, Malmendier and Tate (2015) revealed that optimistic managers in financially constrained firms are more sensitive to cash holding and defer current investment with external financing. A few years ago, Huang-Meier et al. (2016) discovered that optimistic managers use internal funding to advance growth opportunity and reduce the need to get external financing. Further, Pikulina et al. (2017) noted that optimism in financially constrained firms induces managers to only invest in value-enhancing projects and this optimism positively contributes to better firm value.

On the other hand, Güner et al. (2008) report that optimistic managers in unconstrained firms engage in higher capital expenditure and excessive investment in mergers and acquisitions, but this leads to an overinvestment problem. According to the overinvestment hypothesis, optimism simply increases cash holding on firm value, because higher cash holding intensifies the overinvestment by investing in value-destroying projects. Tran et al. (2020) recently revealed that optimistic managers seek external financing but despite its cost they are adamant that such problems are overcome by value-generating projects. Consistent with these arguments, Malmendier et al. (2007) noted that optimists overestimate project cash flows and want to invest more with available adequate cash holding and external finance.

Briefly, managerial optimism influences the financing and investment policy of a firm. Optimistic managers are more cautious about internal cash holding and reluctant to seek external finance. In financially constrained firms, optimistic managers may only invest in viable NPV projects, which may promote the underinvestment problem. This problem abates due to the generation of cash from a successful NPV project, and it is reinvested in other schemes. For financially unconstrained firms, managerial optimism promotes an overinvestment problem by investing in value-decreasing projects, which will have grave implications for firm value. It means that managerial optimism increases the effect of cash holding on firm value, and based on this, the following hypotheses are stated: 
Hypothesis 4. Managerial optimism may increase the effect of cash holding on firm value.

Hypothesis 5. In financially constrained firms, managerial optimism may increase the positive effect of cash holding on firm value.

Hypothesis 6. In financially unconstrained firms, managerial optimism may increase the negative effect of cash holding on firm value.

\section{Data and Methodology}

\subsection{Data Explanation}

The Chinese Stock Market and Accounting Research (CSMAR) data center was used to extract the financial data of firms listed on the Shehzian Stock Exchange (SSE). CSMAR data-house is a more reliable data center, because it provides the relevant data for financial research and analysis. The CSMAR maintains the finance-related data of 3156 manufacturing firms listed on the SSE for the period 2009-2019. This study comprised firms which had a complete record of executive earnings forecast, corporate governance, and financial characteristics for the years 2009 to 2019. We obtained a sample of 1745 firms out of 3156 having the complete dataset of all variables for this particular decade. The data were normalized by removing $1 \%$ outliers from the whole dataset. Further, Cronbach's alpha statistics were applied to test the data reliability. The alpha value (0.79) means that data are normally distributed and reliable for research analysis.

\subsection{Variables Explanation}

This study aims to analyze the influence of cash holding on firm value in the context of managerial optimism. Table 1 illustrates the description of the variables and the acronyms used in the study. The dependent variable Tobin's $Q$ served as a measure of firm value. Tobin's $Q$ is a more comprehensive proxy of firm value, as it reflects stock market value divided by total assets. The $\mathrm{Q}$ model is an investment model that can help us to analyze the investment cash flows sensitivity (Han and Qiu 2007; Mohamed et al. 2014; Lin et al. 2005; Ariff et al. 2021). The independent variable Cash Holding (CH) is the proxy of firm cash and cash equivalent divided by total assets. The following control variables-Leverage (LEV), Firm Size (FS), and Sales Growth (SGW) - were expected to affect the firm value and influence decisions made on cash holding.

Table 1. Variables descriptions and their acronyms.

\begin{tabular}{|c|c|c|c|c|}
\hline \multirow[t]{2}{*}{ Variables } & \multirow[t]{2}{*}{ Acronym } & \multirow[t]{2}{*}{ Estimation } & \multicolumn{2}{|c|}{ Multicollinearity } \\
\hline & & & Tolr & VIF \\
\hline Firm Value & Tobin Q & $\begin{array}{l}\text { Market value of equity }+ \text { market value } \\
\text { of a preferred } \\
\text { stock }+ \text { market value of debt/divided } \\
\text { by book value of assets }\end{array}$ & & \\
\hline $\begin{array}{l}\text { Managerial } \\
\text { Optimism }\end{array}$ & M.Opt & $\begin{array}{l}\text { actual earnings are less than forecast } \\
\text { earnings }\end{array}$ & 0.89 & 1.19 \\
\hline Cass Holding & $\mathrm{CH}$ & Cash and cash equivalent/total assets & 0.87 & 1.23 \\
\hline Leverage & LEV & Long term debt/total assets & 0.75 & 1.34 \\
\hline Firm Size & FS & Long term assets/total assets & & \\
\hline Sales Growth & SGW & Percentage change in annual sales & & \\
\hline $\begin{array}{c}\text { CEO } \\
\text { Ownership }\end{array}$ & CEO Own & $\begin{array}{l}\text { Total worth of shares held by CEO in a } \\
\text { year/total shares outstanding }\end{array}$ & & \\
\hline $\begin{array}{l}\text { Independent } \\
\text { Director }\end{array}$ & Indept & $\begin{array}{l}\text { Dummy variable } 1 \text { for an independent } \\
\text { director in a board and } 0 \text { otherwise }\end{array}$ & & \\
\hline $\begin{array}{l}\text { Director's } \\
\text { Tenure }\end{array}$ & Tenure & Director's total time serve in a board & & \\
\hline Gender & $\mathrm{M} / \mathrm{F}$ & $\begin{array}{l}\text { Dummy variable } 1 \text { for male and } 0 \text { for } \\
\text { female }\end{array}$ & & \\
\hline
\end{tabular}




\subsection{Corporate Governance Variable}

Prior studies assert that the internal structure of corporate governance also significantly influences the firms' cash holding decisions. Malmendier and Tate (2005) explain that an independent board helps to minimize the cash flows sensitivity concerning investment decisions. Similarly, Donnelly and Mulcahy (2008) predict that a balanced board of directors helps to explain the efficient level of cash holding on the issue of investment decisions. Mohamed et al. (2014) use corporate governance variables like board structure, board size, board tenure, and board education to detect the influence of cash flow sensitivity on corporate investment decisions. This study employed corporate governance variables, such as CEO ownership, independent directors, director tenure, and directors' gender, to examine firms' cash holding decisions.

\subsection{Division of Constrained and Unconstrained Firms}

Published studies used numerous statistical techniques and finance-related measures for financially constrained and unconstrained firms. As an example, Fazzari et al. (1988) and Allayannis and Mozumdar (2004) use cash flow sensitivity to classify financially constrained firms. Further, Whited and Wu (2006) develop a likelihood ratio of six firms and relative industry-specific futures, in order to identify financially constrained firms. Likewise, Whited (1992) and Almeida and Campello (2007) use the Standard and Poor (S\&P) corporate bond rating, while Lu and Jhuang (2014) employ the leverage ratio to differentiate financially constrained firms from non-constrained firms. This study extends the classification scheme of Ferrando and Ruggieri (2018) to measure the financial constraints experienced by a firm. We developed a more rigorous classification scheme in Table 2 of firms' financial characteristics to specify the actual constraints encountered.

Table 2. Classification of the constrained and unconstrained firms.

\begin{tabular}{|c|c|c|c|c|c|c|}
\hline $\begin{array}{l}\text { Total } \\
\text { Firms }\end{array}$ & WCR & CHR & DFR & OCFR & RER & DPR \\
\hline \multicolumn{7}{|c|}{ Absolutely constrained firms } \\
\hline & $\leq 0$ & $\geq 0$ & $\geq$ Avg & $\leq 0$ & $\geq \operatorname{Avg}$ & $\leq 0$ \\
\hline & 244 & 244 & 244 & 244 & 244 & 244 \\
\hline \multicolumn{7}{|c|}{ Relatively constrained firms } \\
\hline & $\geq 0$ & $\leq 0$ & $\leq$ Avg & $\leq 0$ & $\geq \operatorname{Avg}$ & $\leq 0$ \\
\hline & 553 & 553 & $553^{\circ}$ & 553 & $553^{\circ}$ & $\overline{553}$ \\
\hline \multicolumn{7}{|c|}{ Unconstrained firms } \\
\hline & $\geq 0$ & $\leq 0$ & $\leq \mathrm{Avg}$ & $\geq 0$ & $\leq \mathrm{Avg}$ & $\geq 0$ \\
\hline & $\overline{948}$ & $\overline{948}$ & $948^{\circ}$ & $\overline{948}$ & 948 & $\overline{948}$ \\
\hline
\end{tabular}

In Table 2, the sample of 244 firms met the criteria of absolutely constrained firms. Absolutely constrained means that firms have a negative working capital rate (WCR), a positive cash holding rate (CHR), an above-average debt financing rate (DFR), a negative change in operating cash flow rate (OCFR), an above-average retain earnings rate (RER), and a negative change in dividend payout ratio (DPR). Firms that meet the absolutely constrained requirement face strict financial conditions, under which generating finance externally is more expensive. On the other hand, 553 firms fulfilled the criteria of relative constrained firms. The relatively constrained firms were in a better financial position (a positive WCR and a below-average DFR) compared to the absolutely constrained firms. The former did encounter difficulty in raising finance externally at a reasonable cost, as they met the minimum criteria (a negative CHR, an above-average RER, and a negative change in DPR) of constrained firms. The relatively constrained firms held less cash but had an opportunity to raise finance externally for viable NPV projects. In contrast, the 948 
unconstrained firms did not face any financial constraint in obtaining finance externally at a lower cost. The unconstrained firms held a positive WCR, a negative CHR, a belowaverage DFR, a positive change in annual OCFR, a below-average RER, and a positive change in DPR.

\subsection{Internal Forecast and Managerial Optimism}

The study used managerial optimism as a moderator to examine the influence of cash holding on firm value. Studies, such as DeAngelo et al. (2002), Wei et al. (2011), Purhanudin and Zakaria (2015), and Ariff et al. (2021), have used the traditional variables of executive holding and exercise of stock options to measure managerial behavioral biases. This study developed a novel technique of earnings forecast errors for each quarter to measure managerial optimism. Firstly, we developed the frequency of firms' actual earnings and forecasting earnings for each quarter from 2009 to 2019. The earnings surplus was the outcome of the actual earnings more than the forecast earnings during a quarter, while the earnings deficit is the actual earnings less than the forecast earnings in a quarter. Managers were considered to be optimistic. if the frequency of earnings deficit was repeated three times in a year. The dummy variable creates 1 for earnings deficit and 0 for earnings surplus in each year. Table 3 summarizes the actual earnings and the earnings forecast of constrained, relatively constrained, and unconstrained firms.

Table 3. Measurement of managerial optimism.

\begin{tabular}{lccccccccccc}
\hline \multicolumn{1}{c}{ Year } & $\mathbf{2 0 0 9}$ & $\mathbf{2 0 1 0}$ & $\mathbf{2 0 1 1}$ & $\mathbf{2 0 1 2}$ & $\mathbf{2 0 1 3}$ & $\mathbf{2 0 1 4}$ & $\mathbf{2 0 1 5}$ & $\mathbf{2 0 1 6}$ & $\mathbf{2 0 1 7}$ & $\mathbf{2 0 1 8}$ & $\mathbf{2 0 1 9}$ \\
\hline Constrained firms & & & & & & & & & & & \\
Total forecasts & 976 & 976 & 976 & 976 & 976 & 976 & 976 & 976 & 976 & 976 & 976 \\
$\begin{array}{l}\text { Deficit forecasts } \\
\text { Surplus }\end{array}$ & 693 & 722 & 745 & 690 & 678 & 736 & 655 & 697 & 733 & 788 & 630 \\
Relatively constrained firms & 283 & 254 & 231 & 286 & 298 & 240 & 321 & 279 & 243 & 188 & 346 \\
Total forecasts & 2212 & 2212 & 2212 & 2212 & 2212 & 2212 & 2212 & 2212 & 2212 & 2212 & 2212 \\
Deficit forecasts & 1467 & 1523 & 1698 & 1590 & 1478 & 1510 & 1540 & 1440 & 1378 & 1390 & 1540 \\
Surplus & 745 & 689 & 514 & 622 & 734 & 702 & 672 & 772 & 834 & 822 & 672 \\
Unconstrained firms & & & & & & & & & & & \\
Total forecasts & 3792 & 3792 & 3792 & 3792 & 3792 & 3792 & 3792 & 3792 & 3792 & 3792 & 3792 \\
Deficit forecasts & 2376 & 2460 & 2430 & 2390 & 2580 & 2510 & 2460 & 2375 & 2444 & 2532 & 2454 \\
Surplus & 1416 & 1332 & 1362 & 1402 & 1212 & 1282 & 1332 & 1417 & 1348 & 1260 & 1338 \\
\hline
\end{tabular}

This research employed econometric techniques to analyze the influence of cash holding on firm value. Firstly, the panel least squares regression model in Equation (1) was used to test hypotheses. Meanwhile, the term Fixed Effect (FE) was used to control the correlation errors in Equation (2). The Hausman test Chi. Sq. Statistics (7.9842) is significant and refers to using FE instead of the Random Effect (RE) method. Moreover, the Generalized Method of Moments (GMM) controls the endogeneity problem and robustness of results in Equation (3). Endogeneity is the consequence of one or more omitted variables in the equation or measurement errors. The instrument variables of lag regression and lag difference of explanatory variables can be used in GMM to remove the endogeneity problem. Finally, we developed the following econometric models to test the influence of cash holding on firm value.

1. Panel least squares regression statistics (OLS)

$$
\begin{gathered}
\text { Tobin's } Q=\beta_{0}+\beta_{1}(\mathrm{CH})+\beta_{2}(\mathrm{CH})^{2}+\beta_{3}(\mathrm{M} . \mathrm{Opt})+\beta_{4}(\mathrm{CH} \times \mathrm{M} . \mathrm{Opt})+\beta_{5}(\mathrm{LEV})+\beta_{6}(\mathrm{FS})+\beta_{7}(\mathrm{GRW})+ \\
\beta_{8}(\mathrm{X})+\mu .
\end{gathered}
$$

\section{Panel FE}

$$
\begin{aligned}
\text { Tobin's }_{\mathrm{i}, \mathrm{t}}=\beta_{0}+\beta_{1}\left(\mathrm{CH}_{\mathrm{i}, \mathrm{t}}\right)+\beta_{2}\left(\mathrm{CH}_{\mathrm{i}, \mathrm{t}}^{2}\right) & +\beta_{3}\left(\mathrm{M}_{\mathrm{O}} \mathrm{Opt} \mathrm{t}_{\mathrm{i}, \mathrm{t}}\right)+\beta_{4}\left(\mathrm{CH}_{\mathrm{i}, \mathrm{t}} \times \mathrm{M}_{\mathrm{O}} \mathrm{Opt} \mathrm{t}_{\mathrm{i}, \mathrm{t}}\right)+\beta_{5}\left(\mathrm{LEV}_{\mathrm{i}, \mathrm{t}}\right)+\beta_{6}\left(\mathrm{FS}_{\mathrm{i}, \mathrm{t}}\right) \\
& +\beta_{7}\left(\mathrm{GRW}_{\mathrm{i}, \mathrm{t}}\right)+\beta_{8}\left(\mathrm{X}_{\mathrm{i}, \mathrm{t}}\right)+\alpha_{\mathrm{i}}+\mu_{\mathrm{i}, \mathrm{t}}
\end{aligned}
$$




\section{GMM}

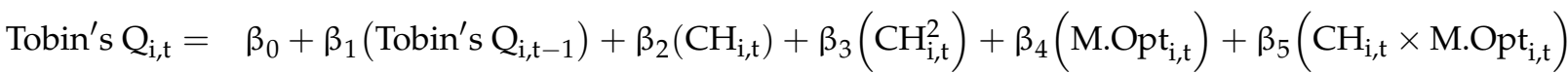

$$
\begin{aligned}
& +\beta_{6}\left(\mathrm{LEV}_{\mathrm{i}, \mathrm{t}}\right)+\beta_{7}\left(\mathrm{FS}_{\mathrm{i}, \mathrm{t}}\right)+\beta_{8}\left(\mathrm{GRW}_{\mathrm{i}, \mathrm{t}}\right)+\beta_{9}\left(\mathrm{X}_{\mathrm{i}, \mathrm{t}}\right),
\end{aligned}
$$

where

Tobin's $Q_{i, t-1}$ is an instrument used to remove endogeneity; $\mu$, and $\mu_{i, t}$ are standards $\mathrm{CH}_{i, t}$, M.Opt $_{i, t}, \mathrm{LEV}_{\mathrm{i}, \mathrm{t}}, \mathrm{FS}_{\mathrm{i}, \mathrm{t}}, \mathrm{GRW}_{\mathrm{i}, \mathrm{t}}$, and $\mathrm{X}_{\mathrm{i}, \mathrm{t}}$;

The vector $X$ in Equation (1), and $X_{i, t}$ in Equations (2) and (3) represent all the corporate governance variables.

\section{Results and Discussion}

\subsection{Descriptive Statistics}

The descriptive statistics reported in Table 4 of the entire sample estimate the Equations (1)-(3). The mean value and the lower standard deviation (0.41) of Tobin's Q (1.24) indicate that only a small number of Tobin's $Q$ observations deviate from its mean. Similarly, the mean value (0.17) and the standard deviation (0.06) of $\mathrm{CH}$ suggest that $\mathrm{CH}$ values are revolving near their mean value. The mean value (0.17) and the median (1.03) of $\mathrm{CH}$ indicate that a large number of firms earned a positive rate of return. The mean values of control variables, LEV, FS, and GRW were $0.54,0.73$, and 0.28 , respectively, while the standard deviations of LEV, FS, and GRW were 0.20, 0.29, and 0.11, respectively, showing that control variables maintained positive mean values and lower standard deviations. The mean value (0.003) and the maximum value (0.14) of CEO Own indicate that the CEO holds a significant amount of stock options every year. Likewise, the mean value (3) of independent directors shows that an average number (3) and the maximum number (6) of independent directors are employed in a company, respectively. Similarly, the mean value of Tenure (3.49) means that, on average, a director serves on the company board for three and half years. Meanwhile, the mean value of Gender (3) reveals that, on average, 3 male directors and 1 female director work on a company board.

Table 4. Descriptive statistics of the whole sample.

\begin{tabular}{lcccccc}
\hline Variables & Observation & Mean & Median & Maximum & Minimum & $\begin{array}{c}\text { Standard } \\
\text { Deviation }\end{array}$ \\
\hline Firm data & & & & & & \\
Tobin's Q & 19,195 & 1.24 & 1.03 & 3.46 & 0.05 & 0.41 \\
CH & 19,195 & 0.17 & 0.09 & 0.55 & -0.22 & 0.06 \\
M.Opt & 19,195 & 7.78 & 4.00 & 1.00 & 0.00 & 3.24 \\
LEV & 19,195 & 0.54 & 0.41 & 0.98 & 0.19 & 0.20 \\
FS & 19,195 & 0.73 & 0.55 & 0.94 & 0.53 & 0.29 \\
GRW & 19,195 & 0.28 & 0.16 & 0.58 & -0.04 & 0.11 \\
Corporate governance data & & & & & \\
CEO Own & 12,450 & 0.003 & 0.00 & 0.14 & 0.00 & 0.01 \\
Indept & 6235 & 3.00 & 1.00 & 6.00 & 0.00 & 0.27 \\
Tenure & 19,195 & 3.49 & 2.07 & 11.0 & 0.02 & 0.35 \\
Gender & 19,195 & 3.00 & 1.87 & 5.00 & 2.00 & 0.41 \\
\hline \multicolumn{7}{l}{} \\
\hline
\end{tabular}

Table 5 shows the results for the descriptive statistics of the absolutely constrained, relatively constrained, and unconstrained firms. In the first group, the mean value of Tobin's Q (1.07) is significantly different from the mean values of Tobin Q (1.16) in the relatively constrained and that of Tobin's Q (1.23) in the unconstrained firms. Similarly, the median value of Tobin's Q (1.01) in the absolutely constrained firms, the median value of Tobin's Q (1.04) in the relatively constrained, and the median value of Tobin's Q (1.10) in the unconstrained firms differ significantly from each other. Likewise, the maximum value of Tobin's Q (2.45) in the absolutely constrained firms is significantly different from the mean value of Tobin's $Q$ (3.15) in the constrained firms and the mean value of Tobin's $Q$ 
(3.46) in the unconstrained firms. The higher values of Tobin's $Q$ in the last group mean that the stocks of the unconstrained firms are traded at a higher price in the market compared to those of the constrained firms. It discloses that unconstrained firms can issue new stocks in the market to raise external finance at a reasonable cost.

In the constrained firms, the mean (0.24) and median values (0.13) of $\mathrm{CH}$ are significantly higher than the mean (0.18) and median values $(0.08)$ of $\mathrm{CH}$ in the relatively constrained and the mean (0.15) and median values (0.09) in the unconstrained firms. The higher mean value of $\mathrm{CH}$ in the constrained firms explains that these businesses maintain higher cash holdings for their operations. The mean values of M.Opt (6.52) in the absolutely constrained and that of M.Opt (7.13) in the relatively constrained firms are not that different from each other, but the mean value of M.Opt (8.33) in the unconstrained firms is slightly higher. Here, it is indicated that managers are more optimistic in unconstrained firms than in absolutely constrained and relatively constrained firms. In an absolutely constrained firm, the mean values of the control variables (LEV: 0.79; FS: 0.81; GRW: 0.18) are not significantly different from the mean values (LEV: 0.69; FS: 0.71; GRW: 0.22) of the relatively constrained firms. However, the mean values of the control variables (LEV: 0.48; FS: 0.73; GRW: 0.33) in the unconstrained firms are very different from those in the absolutely constrained and relatively constrained firms. It emerges that unconstrained firms have lower leverage, are large in size and experience higher growth than absolutely constrained and relatively constrained firms.

Table 5. Descriptive statistics of the absolutely constrained and unconstrained firms.

\begin{tabular}{|c|c|c|c|c|c|c|c|c|c|c|}
\hline Variables & $\begin{array}{c}\text { Tobin's } \\
\text { Q }\end{array}$ & $\mathrm{CH}$ & M.Opt & LEV & FS & GRW & $\begin{array}{l}\text { CEO } \\
\text { Own }\end{array}$ & Indept & Tenure & Gender \\
\hline \multicolumn{11}{|c|}{ Absolutely constrained } \\
\hline Observations & 2684 & 2684 & 2684 & 2684 & 2684 & 2684 & 1680 & 1070 & 2684 & 2684 \\
\hline Mean & 1.07 & 0.24 & 6.52 & 0.79 & 0.81 & 0.18 & 0.002 & 2.53 & 3.03 & 4.00 \\
\hline Median & 1.01 & 0.13 & 4.45 & 0.65 & 0.56 & 0.05 & 0.001 & 1.78 & 2.43 & 2.00 \\
\hline Maximum & 2.45 & 0.23 & 1.00 & 0.98 & 0.94 & 0.19 & 0.050 & 4.00 & 7.00 & 5.00 \\
\hline Minimum & 0.06 & -0.22 & 0.00 & 0.55 & 0.53 & -0.04 & 0.00 & 0.00 & 0.50 & 2.00 \\
\hline \multicolumn{11}{|c|}{ Relatively constrained } \\
\hline Observations & 6083 & 6083 & 6083 & 6083 & 6083 & 6083 & 3458 & 1940 & 6083 & 6083 \\
\hline Mean & 1.16 & 0.18 & 7.13 & 0.69 & 0.79 & 0.22 & 0.003 & 3.50 & 4.45 & 3.00 \\
\hline Median & 1.04 & 0.08 & 4.67 & 0.54 & 0.58 & 0.06 & 0.001 & 2.00 & 3.09 & 2.00 \\
\hline Maximum & 3.15 & 0.32 & 1.00 & 0.86 & 0.87 & 0.32 & 0.000 & 6.00 & 7.00 & 4.00 \\
\hline Minimum & 0.08 & -0.15 & 0.00 & 0.51 & 0.57 & 0.02 & 0.060 & 0.01 & 1.30 & 1.00 \\
\hline \multicolumn{11}{|l|}{ Unconstrained } \\
\hline Observations & 10,428 & 10,428 & 10,428 & 10,428 & 10,428 & 10,428 & 7332 & 3225 & 10,428 & 10,428 \\
\hline Mean & 1.23 & 0.15 & 8.33 & 0.48 & 0.73 & 0.33 & 0.005 & 3.69 & 3.76 & 3.45 \\
\hline Median & 1.10 & 0.09 & 5.81 & 0.39 & 0.61 & 0.21 & 0.003 & 2.78 & 3.00 & 2.98 \\
\hline Maximum & 3.46 & 0.55 & 1.00 & 0.65 & 0.81 & 0.58 & 0.14 & 6.00 & 11.0 & 5.00 \\
\hline Minimum & 0.05 & 0.03 & 0.00 & 0.20 & 0.58 & 0.10 & 0.00 & 1.00 & 1.00 & 0.03 \\
\hline
\end{tabular}

The corporate governance variables, the mean values of CEO Own (0.002), Indept (2.53), Tenure (3.03), and Gender (4) in the absolutely constrained firms and the mean values of CEO Own (0.003), Indept (3.50), Tenure (4.45), and Gender (3) in the relatively constrained firms do not significantly differ from each other. However, the mean values of CEO Own (0.005), Indept (3.69), Tenure (4.76), and Gender (3.45) are very different between the remaining two groups. The median, maximum, and minimum values of all variables as reported in Table 5, which help us to understand the entire dataset of all variables. Results are consistent with the work done by Deshmukh et al. (2021), Ding et al. (2013), Bigelli and Sánchez-Vidal (2012), and Denis and Sibilkov (2010). 


\subsection{Pearson Correlation Matrix}

In Table 6, the upper part is the correlation among the variables in the absolutely constrained firms, while the lower part is the correlation among the variables in the relatively constrained firms. In contrast, Table 7 shows the correlation among the variables in the financially unconstrained firms. Significant negative correlations were found between Tobin's Q and CH in the absolutely constrained firms $(-0.41)$ and the relatively constrained firms (-0.33). In contrast, in Table 7, a significant positive correlation between Tobin's $\mathrm{Q}$ and $\mathrm{CH}$ was identified (0.45) in the unconstrained firms. Suggested here is an inverse relationship developed between firm value and cash flows. These results are similar to those of Almeida and Campello (2007), Denis and Sibilkov (2010), and Faulkender and Wang (2006).

Table 6. Correlation matrix of the financially absolutely constrained and relatively constrained firms.

\begin{tabular}{|c|c|c|c|c|c|c|c|c|c|c|}
\hline Variables & Tobin's Q & $\mathrm{CH}$ & M.Opt & LEV & FS & GRW & CEO Own & Indept & Tenure & Gender \\
\hline Tobin's Q & 7 & $-0.41^{a}$ & $0.24^{\mathrm{a}}$ & $-0.25^{a}$ & $0.31^{a}$ & $0.27^{a}$ & $0.16^{\mathrm{a}}$ & $0.12^{a}$ & $0.14^{\mathrm{a}}$ & $0.17^{a}$ \\
\hline $\mathrm{CH}$ & -0.33 a & & $0.27 \mathrm{a}$ & $0.17^{a}$ & $0.14^{a}$ & $0.11^{a}$ & $0.14^{\mathrm{a}}$ & 0.07 a & 0.06 & $0.08^{c}$ \\
\hline M.Opt & 0.19 a & 0.23 a & & $0.15^{b}$ & $0.10^{a}$ & $0.04 \mathrm{~b}$ & 0.12 a & $0.16^{\text {a }}$ & $0.10^{a}$ & 0.12 a \\
\hline LEV & $0.24^{a}$ & $0.15^{a}$ & 0.13 a & & 0.20 a & -0.19 a & 0.17 a & 0.12 a & $0.09 \mathrm{c}$ & $0.07 \mathrm{~b}$ \\
\hline FS & $0.28^{a}$ & $0.22^{a}$ & $0.17^{a}$ & $0.23^{a}$ & & $0.22^{a}$ & $0.11^{a}$ & $0.14^{c}$ & 0.09 a & $0.11^{b}$ \\
\hline GRW & $0.25^{a}$ & $0.15^{\mathrm{a}}$ & $0.09 \mathrm{~b}$ & $-0.15^{\text {a }}$ & $0.18^{a}$ & & $0.12^{b}$ & $0.14^{b}$ & $0.07 \mathrm{~b}$ & $0.10^{b}$ \\
\hline CEO Own & $0.13^{a}$ & $0.19 \mathrm{~b}$ & $0.14^{a}$ & $0.11^{a}$ & $0.10^{a}$ & $0.17 \mathrm{~b}$ & & $-0.09 \mathrm{c}$ & $0.11^{b}$ & $0.07^{b}$ \\
\hline Indept & $0.17^{a}$ & $0.13^{a}$ & $0.03^{a}$ & $0.14^{b}$ & $0.09 \mathrm{c}$ & 0.17 c & $0.07^{b}$ & & $-0.06^{b}$ & $0.04^{b}$ \\
\hline Tenure & $0.21^{b}$ & $0.17 \mathrm{~b}$ & $0.11^{c}$ & $0.18^{b}$ & $0.15^{b}$ & $0.14^{b}$ & $0.11^{b}$ & $0.10^{b}$ & & $0.06^{c}$ \\
\hline Gender & $0.11^{\text {a }}$ & 0.09 a & $0.06^{c}$ & $0.08^{c}$ & $0.10^{c}$ & $0.07 \mathrm{c}$ & $0.12 \mathrm{c}$ & $0.09 \mathrm{c}$ & $0.11^{c}$ & \\
\hline
\end{tabular}

$\mathrm{a}=$ significant at $0.01{ }^{\mathrm{b}}=$ significant at $0.05 ;{ }^{\mathrm{c}}=$ significant at 0.10.

Similarly, a positive correlation exists between Tobin's Q and M.Opt (0.24), CH, and M.Opt (0.27) in the absolutely constrained firms. Likewise, a positive correlation is evident between Tobin's Q and M.Opt (0.19), CH, and M.Opt (0.23) in the relatively constrained firms. In contrast, the Tobin's Q and M.Opt $(-0.18), \mathrm{CH}$, and M.Opt $(-0.21)$ are significantly negatively correlated in the unconstrained firms. It was revealed that optimistic managers of constrained firms prefer to hold cash and invest in value-enhancing projects and business deals. Conversely, unconstrained firms' funds, if in adequate amounts, are available for investment, and optimistic managers overinvest in value-decreasing projects, which may well damage firm value. The findings are similar to those documented by Faulkender and Wang (2006), Ferrando and Ruggieri (2018), and Huang-Meier et al. (2016).

In the absolutely constrained firms, control variables FS and GRW are 0.31 and 0.27 , respectively, which develop significant positive correlations with Tobin's Q. Similarly, in the relatively constrained firms, FS (0.28) and GRW (0.25) are positively associated with Tobin's Q. In the meantime, in the absolutely constrained firms, the control variable LEV $(-0.25)$ and Tobin's $Q$ are negatively correlated with each other. The negative correlation between leverage and firm value indicates that the constrained firms pay more for financing growth opportunities. In the relative constrained firms, the control variable LEV (0.24) is significantly positively correlated with Tobin's Q. It indicates that relatively constrained firms still have an opportunity to find external finance for investing in good NPV projects. The results are consistent with studies by Ferrando and Ruggieri (2018), Khatami et al. (2015), and Martínez-Sola et al. (2013).

In Table 7, the control variables (LEV: 0.33; FS: 0.26; GRW: 0.29) develop positive correlations with Tobin's $Q$ in the unconstrained firms. The positive correlation between LEV and Tobin's $Q$ indicates that unconstrained firms may raise finance at a reasonable cost when investment opportunities beckon. The corporate governance variables CEO own, Indept, Tenure, and Gender are significantly positively correlated with Tobin's Q in the constrained, relatively constrained, and unconstrained firms, respectively. The corporate 
governance variables CEO own, Indept, Tenure, and Gender also develop significant correlations with firms' cash holdings, which indicates that firms' internal management teams influence cash holding decisions and investment policies.

Table 7. Correlation matrix of the financially unconstrained firms.

\begin{tabular}{|c|c|c|c|c|c|c|c|c|c|c|}
\hline Variables & $\begin{array}{c}\text { Tobin's } \\
\text { Q }\end{array}$ & $\mathrm{CH}$ & M.Opt & LEV & FS & GRW & $\begin{array}{l}\text { CEO } \\
\text { Own }\end{array}$ & Indept & Tenure & Gender \\
\hline $\begin{array}{l}\text { Tobin's } \\
\text { Q }\end{array}$ & 1 & & & & & & & & & \\
\hline $\mathrm{CH}$ & $0.45^{\mathrm{a}}$ & 1 & & & & & & & & \\
\hline M.Opt & $-0.18^{\mathrm{a}}$ & $-0.21^{\mathrm{a}}$ & 1 & & & & & & & \\
\hline LEV & $0.33^{\mathrm{a}}$ & $0.15^{\mathrm{a}}$ & $0.13^{a}$ & 1 & & & & & & \\
\hline FS & $0.26^{\mathrm{a}}$ & $0.22^{\mathrm{a}}$ & $0.17^{\mathrm{a}}$ & $0.23^{a}$ & 1 & & & & & \\
\hline GRW & $0.29^{a}$ & $0.15^{\mathrm{a}}$ & $0.09^{b}$ & $0.15^{\mathrm{a}}$ & $0.18^{a}$ & 1 & & & & \\
\hline $\begin{array}{l}\text { CEO } \\
\text { Own }\end{array}$ & $0.14^{\mathrm{a}}$ & $0.16^{b}$ & $0.14^{\mathrm{a}}$ & $0.14^{\mathrm{a}}$ & $0.11^{a}$ & $0.14^{b}$ & 1 & & & \\
\hline Indept & $0.16^{\mathrm{a}}$ & $0.14^{\mathrm{a}}$ & $0.04^{\mathrm{a}}$ & $0.13^{b}$ & $0.11^{\mathrm{c}}$ & $0.15^{c}$ & $0.09^{b}$ & 1 & & \\
\hline Tenure & $0.22^{b}$ & $0.15^{b}$ & $0.12^{\mathrm{c}}$ & $0.16^{b}$ & $0.14^{b}$ & $0.13^{b}$ & $0.09^{b}$ & $0.11^{\mathrm{b}}$ & 1 & \\
\hline Gender & $0.12^{\mathrm{a}}$ & $0.10^{\mathrm{a}}$ & $0.07^{\mathrm{c}}$ & $0.05^{\mathrm{c}}$ & $0.09^{c}$ & $0.08^{c}$ & $0.11^{\mathrm{c}}$ & $0.08^{\mathrm{c}}$ & $0.12^{\mathrm{c}}$ & 1 \\
\hline
\end{tabular}

${ }^{\mathrm{a}}=$ significant at $0.01 ;^{\mathrm{b}}=$ significant at $0.05 ;^{\mathrm{c}}=$ significant at 0.10 .

\subsection{Regression Analysis}

The regression analysis of OLS, FE, and GMM presented in Table 8 reveals the influence of cash holding on firm value in financially constrained and unconstrained firms by using Equations (1)-(3). The term $\mathrm{CH}^{2}$ was devised to find the nonlinear relationship between firm value and cash flows. $\mathrm{CH}^{2}$ develops a significant negative relationship with Tobin's $\mathrm{Q}$ in absolutely constrained, relatively constrained, and unconstrained firms in OLS, FE, and GMM, respectively. The negative effect of $\mathrm{CH}^{2}$ on Tobin's $\mathrm{Q}$ reveals that cash flows develop the nonlinear relationship with the firm value, so here hypothesis 1 is supported. The explanatory variable $\mathrm{CH}(-0.041$ in OLS), ( -0.040 in FE), and $(-0.033$ in GMM) significantly negatively influences firm value in the absolutely constrained firms, as proposed in hypothesis 2 . The absolutely constrained firms hold more cash and engage in costly external financing. The higher cash holding, the opportunity, and the financing cost of cash holding negatively influence firm value.

In the unconstrained firms, $\mathrm{CH}$ (0.043 in OLS, 0.034 in FE, and 0.031 in GMM) significantly positively influences firm value, as proposed in hypothesis 3 . The unconstrained firms can finance externally at a lower cost and do not accumulate large cash reserves for investment opportunities. The lower cash holding diminishes the opportunity and asymmetric cost of capital, which positively influences firm value. Further, in the relatively constrained firms, $\mathrm{CH}$ (0.034 in OLS, 0.030 in FE, and 0.028 in GMM) develops a significant positive impact on firm value. The relatively constrained firms maintain not only smaller cash holding, but also the opportunity to finance externally at a reasonable cost. A lower cash holding level reduces the financing and opportunity cost of capital, which positively influences firm value as pointed out in our second research question. The $\mathrm{CH}$ has strong explanatory power to explain firm value. The results suggested that a robust and significant relationship exists between internal funds availability and firm value and are consistent with the research by Gao et al. (2013), Kim et al. (2011), Denis and Sibilkov (2010), Almeida and Campello (2007), and Faulkender and Wang (2006). 
Table 8. Relationships between the cash holding and the value of firms.

\begin{tabular}{|c|c|c|c|c|c|c|c|c|c|}
\hline \multicolumn{4}{|c|}{ Dep Variable Absolutely Constrained Firms } & \multicolumn{3}{|c|}{ Relatively Constrained Firms } & \multicolumn{3}{|c|}{ Unconstrained Firms } \\
\hline Tobin's Q & OLS & FE & GMM & OLS & FE & GMM & OLS & FE & GMM \\
\hline $\begin{array}{l}\text { Tobin's } \\
Q(-1)\end{array}$ & & & $0.001^{\mathrm{a}}$ & & & $0.003^{a}$ & & & $0.001^{\mathrm{a}}$ \\
\hline $\mathrm{CH}$ & $-0.041^{\mathrm{a}}$ & $-0.040^{\mathrm{a}}$ & $-0.033^{a}$ & $0.034^{\mathrm{a}}$ & $0.030^{\mathrm{a}}$ & $0.028^{a}$ & $0.043^{\mathrm{a}}$ & $0.034^{\mathrm{a}}$ & $0.031^{\mathrm{a}}$ \\
\hline $\mathrm{CH}^{2}$ & $-0.041^{\mathrm{a}}$ & $-0.032^{\mathrm{a}}$ & $-0.031^{\mathrm{a}}$ & $-0.043^{\mathrm{a}}$ & $-0.041^{\mathrm{a}}$ & $-0.039^{a}$ & $-0.038^{a}$ & $-0.037^{\mathrm{a}}$ & $-0.029^{a}$ \\
\hline LEV & $-0.023^{a}$ & $-0.018^{a}$ & $-0.017^{\mathrm{a}}$ & $0.021^{\mathrm{a}}$ & $0.020^{\mathrm{a}}$ & $0.020^{\mathrm{a}}$ & $0.041^{\mathrm{a}}$ & $0.038^{\mathrm{a}}$ & $0.031^{\mathrm{a}}$ \\
\hline FS & $0.031^{\mathrm{a}}$ & $0.028^{a}$ & $0.022^{\mathrm{a}}$ & $0.027^{\mathrm{a}}$ & $0.023^{a}$ & $0.018^{\mathrm{b}}$ & $0.034^{\mathrm{a}}$ & $0.029^{a}$ & $0.021^{\mathrm{b}}$ \\
\hline GRW & $0.067^{\mathrm{a}}$ & $0.065^{\mathrm{a}}$ & $0.051^{\mathrm{a}}$ & $0.071^{\mathrm{a}}$ & $0.067^{\mathrm{a}}$ & $0.051^{\mathrm{a}}$ & $0.066^{\mathrm{a}}$ & $0.061^{a}$ & $0.051^{\mathrm{a}}$ \\
\hline CEO Own & $0.003^{\mathrm{a}}$ & $0.003^{\mathrm{a}}$ & $0.001^{\mathrm{a}}$ & $0.005^{\mathrm{a}}$ & $0.003^{b}$ & $0.002^{b}$ & $0.004^{\mathrm{a}}$ & $0.003^{b}$ & $0.001^{\mathrm{c}}$ \\
\hline Indept & $0.006^{b}$ & $0.005^{b}$ & $0.003^{b}$ & $0.004^{b}$ & $0.004^{b}$ & $0.002^{c}$ & $0.005^{\mathrm{a}}$ & $0.003^{c}$ & $0.002^{c}$ \\
\hline Tenure & $0.004^{\mathrm{a}}$ & $0.004^{b}$ & $0.001^{\mathrm{c}}$ & $0.003^{a}$ & $0.002^{b}$ & $0.002^{c}$ & $0.005^{\mathrm{a}}$ & $0.004^{\mathrm{a}}$ & $0.001^{\mathrm{b}}$ \\
\hline Gender & $0.003^{\mathrm{a}}$ & $0.002^{\mathrm{a}}$ & $0.001^{b}$ & $0.004^{\mathrm{a}}$ & $0.003^{b}$ & $0.003^{b}$ & $0.002^{\mathrm{a}}$ & $0.002^{b}$ & $0.001^{\mathrm{c}}$ \\
\hline R-Square & 0.32 & 0.27 & & 0.29 & 0.23 & & 0.33 & 0.28 & \\
\hline $\begin{array}{l}\text { Arelano } \\
\text { Bond }\end{array}$ & & & $-2.291^{a}$ & & & $-2.224^{a}$ & & & $-2.238^{a}$ \\
\hline 1st Order & & & $-0.636^{a}$ & & & $-0.987^{a}$ & & & $0.658^{a}$ \\
\hline
\end{tabular}

${ }^{\mathrm{a}}=$ significant at $0.01 ;^{\mathrm{b}}=$ significant at $0.05 ;{ }^{\mathrm{c}}=$ significant at 0.10.

The study also analyzed cash holding in the context of managerial optimism on firm value in Table 9. Managerial optimism M.Opt (0.041 in OLS, 0.032 in FE, and 0.031 in GMM) significantly positively influences firm value in the absolutely constrained firms. Similarly, in the relatively constrained firms, managerial optimism M.Opt (0.040 in OLS, 0.039 in FE, and 0.034 in GMM) wields a significant positive effect on firm value. Meanwhile, firm value is significantly negatively influenced by managerial optimism M.Opt $(-0.031$ in OLS, -0.030 in FE, and -0.029 in GMM) in the unconstrained firms. It indicates that managerial optimism also significantly influences firm value, as proposed in hypothesis 4 .

To check whether managerial optimism plays a moderating role, we used the interaction term of (M.Opt $\times \mathrm{CH})$ to examine the influence of cash holding on firm value. The interaction term of (M.Opt $\times \mathrm{CH} ; 0.072$ in OLS, 0.069 in FE, and 0.065 in GMM) positively influences firm value in the absolutely constrained firms, as proposed in hypothesis (5). Similarly, in the relatively constrained firms, interaction terms (M.Opt $\times \mathrm{CH} ; 0.064$ in OLS, 0.054 in FE, and 0.052 in GMM) do have a significant positive effect on firm value. Referring to the unconstrained firms, the interaction term of (M.Opt $\times \mathrm{CH} ;-0.043$ in OLS, -0.041 in FE, and -0.036 in GMM) enhances the significant negative effect on firm value, as proposed in hypothesis 6 . The results are consistent with other studies (Malmendier and Tate 2005; Lin et al. 2005; Huang-Meier et al. 2016; Campello and Graham 2013).

Optimistic managers are more cautious about the internal cash holding of a firm and reluctant to seek external finance. In cash-rich firms, managerial optimism worsens an overinvestment problem by investing in value-reducing projects and, in turn, undermines firm value. In cash-constrained and relatively constrained firms, optimistic managers may only invest in those NPV projects likely to produce a good profit, which may promote an underinvestment problem. This problem gradually falls away due to the generation of cash when a NPV project succeeds, and money is reinvested in other projects. We also added some corporate governance variables and examined whether firm governance structure significantly affects the firm's cash holding policy. The corporate governance variables CEO Own, Indept, Tenure, and Gender in the absolutely constrained and relatively constrained firms develop significant positive associations with Tobin's Q. Likewise, in the unconstrained firms, the corporate governance variables Indept, Tenure, and Gender develop significant positive associations with Tobin's $\mathrm{Q}$. With reference to those in the unconstrained firms, CEO own (CEO Own; -0.004 in OLS, -0.002 in FE, and -0.001 in GM) develops a significant negative association with Tobin's $Q$. It means that in the unconstrained firms, optimistic managers may invest more in schemes to earn a higher return but 
at the risk of compromising firm value. Further, the control variables significantly influence firm value, which indicates that our model is correctly specified for estimation purposes.

Table 9. Managerial optimism, cash holding, and firm performance.

\begin{tabular}{|c|c|c|c|c|c|c|c|c|c|}
\hline \multicolumn{4}{|c|}{ Dep Variable Absolutely Constrained Firms } & \multicolumn{3}{|c|}{ Relatively Constrained Firms } & \multicolumn{3}{|c|}{ Unconstrained Firms } \\
\hline Tobin's Q & OLS & FE & Tobin.Q & OLS & FE & Tobin.Q & OLS & FE & Tobin.Q \\
\hline $\begin{array}{l}\text { Tobin's } \\
\mathrm{Q}(-1)\end{array}$ & & & $0.003^{\mathrm{a}}$ & & & $0.002^{\mathrm{a}}$ & & & $0.001^{\mathrm{a}}$ \\
\hline $\mathrm{CH}$ & $0.058^{\mathrm{a}}$ & $0.050^{\mathrm{a}}$ & $0.047^{\mathrm{a}}$ & $0.051^{\mathrm{a}}$ & $0.049^{\mathrm{a}}$ & $0.043^{\mathrm{a}}$ & $-0.039^{a}$ & $-0.037^{\mathrm{a}}$ & $-0.034^{\mathrm{a}}$ \\
\hline M.Opt & $0.041^{\mathrm{a}}$ & $0.032^{\mathrm{a}}$ & $0.031^{\mathrm{a}}$ & $0.040^{\mathrm{a}}$ & $0.039^{\mathrm{a}}$ & $0.034^{\mathrm{a}}$ & $-0.031^{\mathrm{a}}$ & $-0.030^{\mathrm{a}}$ & $-0.029^{a}$ \\
\hline $\begin{array}{l}\mathrm{CH} \times \\
\text { M.Opt }\end{array}$ & $0.072^{a}$ & $0.069^{\mathrm{a}}$ & $0.065^{\mathrm{a}}$ & $0.064^{\mathrm{a}}$ & $0.054^{\mathrm{a}}$ & $0.052^{a}$ & $-0.043^{a}$ & $-0.041^{\mathrm{a}}$ & $-0.036^{\mathrm{a}}$ \\
\hline LEV & $0.024^{\mathrm{a}}$ & $0.022^{\mathrm{a}}$ & $0.019^{\mathrm{a}}$ & $0.052^{\mathrm{a}}$ & $0.046^{\mathrm{a}}$ & $0.037^{\mathrm{a}}$ & $-0.040^{\mathrm{a}}$ & $-0.037^{\mathrm{a}}$ & $-0.033^{a}$ \\
\hline FS & $0.032^{\mathrm{a}}$ & $0.028^{a}$ & $0.023^{a}$ & $0.028^{\mathrm{a}}$ & $0.024^{\mathrm{a}}$ & $0.022^{a}$ & $0.033^{\mathrm{a}}$ & $0.031^{\mathrm{a}}$ & $0.027^{a}$ \\
\hline GRW & $0.059^{a}$ & $0.055^{\mathrm{a}}$ & $0.052^{a}$ & $0.069^{a}$ & $0.063^{\mathrm{a}}$ & $0.054^{\mathrm{a}}$ & $0.063^{\mathrm{a}}$ & $0.060^{\mathrm{a}}$ & $0.056^{\mathrm{a}}$ \\
\hline CEO Own & $0.002^{\mathrm{a}}$ & $0.001^{\mathrm{a}}$ & $0.001^{a}$ & $0.004^{\mathrm{a}}$ & $0.003^{b}$ & $0.003^{b}$ & $-0.004^{\mathrm{a}}$ & $-0.002^{b}$ & $-0.001^{\mathrm{c}}$ \\
\hline Indept & $0.006^{b}$ & $0.005^{b}$ & $0.003^{b}$ & $0.003^{b}$ & $0.002^{b}$ & $0.002^{c}$ & $0.005^{\mathrm{a}}$ & $0.003^{c}$ & $0.002^{c}$ \\
\hline Tenure & $0.004^{\mathrm{a}}$ & $0.004^{b}$ & $0.001^{c}$ & $0.003^{a}$ & $0.002^{b}$ & $0.002^{c}$ & $0.005^{\mathrm{a}}$ & $0.004^{\mathrm{a}}$ & $0.001^{b}$ \\
\hline Gender & $0.003^{a}$ & $0.002^{\mathrm{a}}$ & $0.001^{b}$ & $0.004^{\mathrm{a}}$ & $0.003^{b}$ & $0.003^{b}$ & $0.002^{\mathrm{a}}$ & $0.002^{b}$ & $0.001^{c}$ \\
\hline $\mathrm{R}$-Square & 0.29 & 0.025 & & 0.31 & 0.28 & & 0.33 & 0.27 & \\
\hline $\begin{array}{c}\text { Arelano } \\
\text { Bond }\end{array}$ & & & $-0.231^{\mathrm{a}}$ & & & & & & \\
\hline 1st Order & & & & & & $-0.253^{a}$ & & & $-0.987^{a}$ \\
\hline 2nd Order & & & $0.595^{a}$ & & & $0.584^{\mathrm{a}}$ & & & $0.786^{\mathrm{a}}$ \\
\hline
\end{tabular}

${ }^{a}=$ significant at $0.01 ;{ }^{b}=$ significant at $0.05 ;{ }^{c}=$ significant at 0.10.

The serial correlation tests performed according to the GMM model in Tables 8 and 9 confirmed that instruments used to estimate the model are valid and correctly specified since we do not reject the null hypothesis of no serial correlation existing in the 2nd order in our models. Hence, the instrument variables used to remove the serial correlation do not correlate with the errors in the GMM model and give the most robust results about the endogeneity problem, which is difficult to remove using the OLS and the FE. Subsequently, the results estimated with the GMM model are more reliable and robust than the OLS and the FE.

\section{Concluding Remarks}

This study examined the influence of cash holdings on firm value in financially constrained and unconstrained firms. The study found that cash holding develops a significant nonlinear relationship with firm value (hypothesis 1). In financially constrained and relatively constrained firms, positive cash holding significantly negatively influences the firm value (hypothesis 2). For financially unconstrained firms, negative cash holding significantly positively influences firm value (hypothesis 3 ). These results mean that financially constrained firms hold more cash, which negatively influences firm value. Financially unconstrained firms hold less cash, which positively influences firm value. Further, the significant effect of managerial optimism on firm value (hypothesis 4) has been confirmed. In absolutely constrained and relatively constrained firms, the interaction term of $(\mathrm{CH} \times \mathrm{M}$.Opt) significantly positively affects firm value (hypothesis 5). Meanwhile, the interaction term of $(\mathrm{CH} \times \mathrm{M}$.Opt $)$ in financially unconstrained firms significantly negatively influences firm value (hypothesis 6). In effect, firms' cash holding decisions are influenced by managerial optimism biases.

Our results make a unique contribution to generalize cash holding in the context of managerial optimism regarding firm value. We also explained how managerial ownership and personal traits of managers influence their companies' cash holding decisions. The study employed a unique measure of managerial optimism and reveals the interactive role of cash holding and optimism on firm value. This study is original in that it considered 
the financial and managerial aspects of cash holding separately to understand the role of firms' cash levels. Further, this research applies a unique structure to segregate firms into absolutely constrained, relatively constrained, and unconstrained firms. Developed here is a novel way of measuring managerial optimism to investigate the role of cash flows, since the traditional cash level measures do not reflect these futures.

Although we collected data from a large number of manufacturing firms listed on Shehzian Stock Exchange (SSE), we did not cover those firms registered on Shanghai Stock Exchange. Further, the research only used firm-specific characteristics to identify a firm's financial constraints and ignored industry-specific factors, which are important in determining the financial strength of a firm. Moreover, the research examined manufacturing firms collectively but does not compare different manufacturing sectors and how cash holding affects their firm value. Future research should be undertaken in non-manufacturing industries because of industry-specific characteristics of financial constraints to reveal the impact of cash holding on firm value.

\section{Managerial Implications}

This study provides important theoretical and managerial implications for manufacturing firms. Theoretically, we documented evidence that a non-linear relationship exists between cash holding and firm value in manufacturing firms operating in China. The results indicated that manufacturing firms' cash level can serve as a proxy for internal cash-generating ability. One important finding is that financially constrained firms are influenced by long-term cash holding and investment policies. Unconstrained firms have a lower level of cash being held, which positively influences firm value. Financially constrained firms hold more cash, which negatively affects firm value. One possible explanation is that excess cash balance increases the alternative cost of cash holding, so a lower rate of return on liquidity investment and double taxation negatively affect firms' value. Likewise, the marginal benefits of cash holding decline, when more cash is held. A higher cash level increases the discretionary power of managers to shape investment decisions, and they will invest in projects that best suit their own interests rather than those of capital providers.

In practical terms, this study suggests that constrained firms do not accumulate cash beyond their limit. A company adopts a rational policy about holding cash and proportion of earnings distributed to shareholders. Constrained firms use cash as a tool to overcome financial constraints and invest in value-enhancing projects, while hard cash is only used for uncertain situations. Further, based on the traditional explanation of a firm's investment decision, this study incorporates the corporate finance behavior approach to explain companies' investment policies. Managerial optimism has significant explanatory power. Firstly, equity holders must be aware of the behavioral biases of CEOs and their sway over investment policies. The firm's corporate structure should efficiently overcome any behavioral biases shown by the CEO regarding investment policies. The problem can be minimized by strengthening the board with more independent directors. The stakeholders should encourage the CEO ownership in their firms. This mechanism can help to discipline the firm's governance structure and ensure the interests of all stakeholders are aligned, and managerial irrationality is reduced. Finally, allegations concerning investment distortions are mainly due to firms' internal financial characteristics and processes, market imperfections, or corporate governance mechanisms. It is now time to pay attention to managerial behavioral bias and personality characteristics that can also trigger under- and overinvestment problems.

Author Contributions: Conceptualization, A.H. and Z.A.; data curation, A.H., methodology, A.H. and M.I.B.; formal analysis, A.H. and Z.A.; original draft preparation, A.H. and Z.A., review and editing, M.I.B. and M.A.K.; supervision, M.I.B. All authors have read and agreed to the published version of the manuscript.

Funding: This research received no external funding. 
Institutional Review Board Statement: Not applicable.

Informed Consent Statement: Not applicable.

Data Availability Statement: Data used in the study may be made available on formal request to corresponding authors.

Conflicts of Interest: No potential conflict of interest is declared by authors.

\section{References}

Adrian, Tobias, Michael Fleming, Or Shachar, and Erik Vogt. 2012. Market liquidity after the financial crisis. Annual Review of Financial Economics 9: 43-83. [CrossRef]

Agarwal, Sumit, Itzhak Ben-David, and Vincent Yao. 2015. Collateral valuation and borrower financial constraints: Evidence from the residential real estate market. Management Science 61: 2220-40. [CrossRef]

Allayannis, George, and Abon Mozumdar. 2004. The impact of negative cash flow and influential observations on investment-cash flow sensitivity estimates. Journal of Banking E Finance 28: 901-30.

Allen, Franklin, Jun Qian, and Meijun Qian. 2007. China's financial system: Past, present, and future. Present, and Future. [CrossRef]

Almeida, Heitor, and Murillo Campello. 2007. Financial constraints, asset tangibility, and corporate investment. The Review of Financial Studies 20: 1429-60. [CrossRef]

Almeida, Auro C., Joe J. Landsberg, and Peter J. Sands. 2004. Parameterisation of 3-PG model for fast-growing Eucalyptus grandis plantations. Forest Ecology and Management 193: 179-95. [CrossRef]

Ariff, Mohamed, Alireza Zarei, and M. Ishaq Bhatti. 2021. Monitoring exchange rate instability in 12 selected Islamic economies. Journal of Behavioral and Experimental Finance 31: 100517. [CrossRef]

Asker, John, Joan Farre-Mensa, and Alexander Ljungqvist. 2015. Corporate investment and stock market listing: A puzzle? The Review of Financial Studies 28: 342-90. [CrossRef]

Bates, Thomas W., Kathleen M. Kahle, and René M. Stulz. 2009. Why do US firms hold so much more cash than they used to? The Journal of Finance 64: 1985-2021. [CrossRef]

Baum, Christopher F., Mustafa Caglayan, Andreas Stephan, and Oleksandr Talavera. 2008. Uncertainty determinants of corporate liquidity. Economic Modelling 25: 833-49. [CrossRef]

Bigelli, Marco, and Javier Sánchez-Vidal. 2012. Cash holdings in private firms. Journal of Banking E Finance 36: 26-35.

Caldentey, Esteban Pérez. 2017. Quantitative Easing (QE), Changes in Global Liquidity, and Financial Instability. International Journal of Political Economy 46: 91-112. [CrossRef]

Campello, Murillo, and Dirk Hackbarth. 2008. Corporate Financing and Investment: The Firm-Level Credit Multiplier. EFA 2008 Athens Meetings Paper, 9 Chalkokondili Street. Athens: Athens Institute for Education \& Research.

Campello, Murillo, and John R. Graham. 2013. Do stock prices influence corporate decisions? Evidence from the technology bubble. Journal of Financial Economics 107: 89-110. [CrossRef]

Chen, I-Ju, and Shin-Hung Lin. 2012. Will managerial optimism affect the investment efficiency of a firm? Procedia Economics and Finance 2: 73-80. [CrossRef]

Dae Mello, Ranjan, Sudha Krishnaswami, and Patrick J. Larkin. 2008. Determinants of corporate cash holdings: Evidence from spin-offs. Journal of Banking \& Finance 32: 1209-20.

DeAngelo, Harry, Linda DeAngelo, and Karen H. Wruck. 2002. Asset liquidity, debt covenants, and managerial discretion in financial distress: The collapse of LA Gear. Journal of Financial Economics 64: 3-34. [CrossRef]

Denis, David J., and Valeriy Sibilkov. 2010. Financial constraints, investment, and the value of cash holdings. The Review of Financial Studies 23: 247-69. [CrossRef]

Deshmukh, Sanjay, Anand M. Goel, and Keith M. Howe. 2021. Do CEO beliefs affect corporate cash holdings? Journal of Corporate Finance 67: 101886. [CrossRef]

Ding, Sai, Alessandra Guariglia, and John Knight. 2013. Investment and financing constraints in China: Does working capital management make a difference? Journal of Banking $\mathcal{E}$ Finance 37: 1490-507.

Dittmar, Amy, Jan Mahrt-Smith, and Henri Servaes. 2003. International corporate governance and corporate cash holdings. Journal of Financial and Quantitative Analysis 38: 111-33. [CrossRef]

Do, Hung Quang, M. Ishaq Bhatti, and Muhammad Shahbaz. 2020. Is 'oil and gas' industry of ASEAN5 countries integrated with the US counterpart? Applied Economics 52: 4112-34. [CrossRef]

Donnelly, Ray, and Mark Mulcahy. 2008. Board structure, ownership, and voluntary disclosure in Ireland. Corporate Governance: An International Review 16: 416-29. [CrossRef]

Easterbrook, Frank H. 1984. Two agency-cost explanations of dividends. The American Economic Review 74: 650-59.

Edwards, Alexander, Casey Schwab, and Terry Shevlin. 2016. Financial constraints and cash tax savings. The Accounting Review 91: 859-81. [CrossRef]

Fang, Hongyan, John R. Nofsinger, and Juan Quan. 2015. The effects of employee stock option plans on operating performance in Chinese firms. Journal of Banking \& Finance 54: 141-59.

Faulkender, Michael, and Rong Wang. 2006. Corporate financial policy and the value of cash. The Journal of Finance 61: 1957-90. [CrossRef] 
Fazzari, Steven, R. Glenn Hubbard, and Bruce Petersen. 1988. Investment, financing decisions, and tax policy. The American Economic Review 78: 200-5.

Ferrando, Annalisa, and Alessandro Ruggieri. 2018. Financial constraints and productivity: Evidence from euro area companies. International Journal of Finance \& Economics 23: 257-82.

Gao, Huasheng, Jarrad Harford, and Kai Li. 2013. Determinants of corporate cash policy: Insights from private firms. Journal of Financial Economics 109: 623-39. [CrossRef]

Güner, A. Burak, Ulrike Malmendier, and Geoffrey Tate. 2008. Financial expertise of directors. Journal of Financial Economics 88: 323-54. [CrossRef]

Han, Seungjin, and Jiaping Qiu. 2007. Corporate precautionary cash holdings. Journal of Corporate Finance 13: 43-57. [CrossRef]

Harford, Jarrad. 1999. Corporate cash reserves and acquisitions. The Journal of Finance 54: 1969-97. [CrossRef]

Heaton, James B. 2002. Managerial optimism and corporate finance. Financial Management 31: 33-45. [CrossRef]

Heyman, Dries, Marc Deloof, and Hubert Ooghe. 2003. The debt maturity structure of small firms in a creditor oriented environment. SSRN. [CrossRef]

Hill, Charles W. L., and Thomas M. Jones. 1992. Stakeholder-agency theory. Journal of Management Studies 29: 131-54. [CrossRef]

$\mathrm{Hu}$, Huajing, Yili Lian, and Chih-Huei Su. 2016. Do bank lending relationships affect corporate cash policy? Review of Accounting and Finance 15: 394-415. [CrossRef]

Huang-Meier, Winifred, Neophytos Lambertides, and James M. Steeley. 2016. Motives for corporate cash holdings: The CEO optimism effect. Review of Quantitative Finance and Accounting 47: 699-732. [CrossRef]

Humphery-Jenner, Mark L., and Ronan G. Powell. 2011. Firm size, takeover profitability, and the effectiveness of the market for corporate control: Does the absence of anti-takeover provisions make a difference? Journal of Corporate Finance 17: 418-37. [CrossRef]

Isshaq, Zangina, Godfred A. Bokpin, and Joseph Mensah Onumah. 2009. Corporate governance, ownership structure, cash holdings, and firm value on the Ghana Stock Exchange. The Journal of Risk Finance 10: 488-99. [CrossRef]

Jensen, Michael C. 1986. Agency costs of free cash flow, corporate finance, and takeovers. The American Economic Review 76: 323-29.

Wei, Jiang, Xiao Min, and Jiaxing You. 2011. Managerial overconfidence and debt maturity structure of firms. China Finance Review International 1: 262-79. [CrossRef]

Jugurnath, Bhavish, Mark Stewart, and Robert Brooks. 2008. Dividend taxation and corporate investment: A comparative study between the classical system and imputation system of dividend taxation in the United States and Australia. Review of Quantitative Finance and Accounting 31: 209-24. [CrossRef]

Keynes, John Maynard, and Fritz Waeger. 1936. Allgemeine Theorie der Beschäftigung, des Zinses und des Geldes. Berlin: Duncker \& Humblot Berlin, vol. 6.

Khatami, Seyed Hossein, Maria-Teresa Marchica, and Roberto Mura. 2015. Corporate acquisitions and financial constraints. International Review of Financial Analysis 40: 107-21. [CrossRef]

Kim, Jiyoung, Hyunjoon Kim, and David Woods. 2011. Determinants of corporate cash-holding levels: An empirical examination of the restaurant industry. International Journal of Hospitality Management 30: 568-74. [CrossRef]

Kraus, Alan, and Robert H. Litzenberger. 1973. A state-preference model of optimal financial leverage. The Journal of Finance 28: 911-22. [CrossRef]

Lin, Yueh-Hsiang, Shing-Yang Hu, and Ming-Shen Chen. 2005. Managerial optimism and corporate investment: Some empirical evidence from Taiwan. Pacific-Basin Finance Journal 13: 523-46. [CrossRef]

Lins, Karl V., Henri Servaes, and Peter Tufano. 2010. What drives corporate liquidity? An international survey of cash holdings and lines of credit. Journal of Financial Economics 98: 160-76. [CrossRef]

Liu, Bai, Yibo Wang, and Yongyi Shou. 2020. Trade credit in emerging economies: An interorganizational power perspective. Industrial Management \& Data Systems 120: 4768-83.

Lu, Wen-Cheng, and Ruo-Ling Jhuang. 2014. Cash flow and growth considering different ownership structure. Journal of Modelling in Management 9: 5-17. [CrossRef]

Malmendier, Ulrike, and Geoffrey Tate. 2005. CEO overconfidence and corporate investment. The Journal of Finance 60: 2661-700. [CrossRef]

Malmendier, Ulrike, and Geoffrey Tate. 2015. Behavioral CEOs: The role of managerial overconfidence. Journal of Economic Perspectives 29: 37-60. [CrossRef]

Malmendier, Ulrike, Geoffrey Tate, and Jonathan Yan. 2007. Corporate Financial Policies with Overconfident Managers. Cambridge: National Bureau of Economic Research.

Martínez-Sola, Cristina, Pedro J. García-Teruel, and Pedro Martínez-Solano. 2013. Corporate cash holding and firm value. Applied Economics 45: 161-70. [CrossRef]

Mohamed, Ezzeddine Ben, and Mohammed Abdelshakour Shehata. 2020. R\&D investment-cash flow sensitivity under managerial optimism. Journal of Behavioral and Experimental Finance 14: 1-4.

Mohamed, Ezzeddine Ben, Nassreddine Garoui, and Kamel Naoui. 2020. Do optimistic managers destroy firm value? Journal of Behavioral and Experimental Finance 26: 100292. [CrossRef]

Mohamed, Ezzeddine Ben, Richard Fairchild, and Abdelfettah Bouri. 2014. Investment cash flow sensitivity under managerial optimism: New evidence from NYSE panel data firms. Journal of Economics Finance and Administrative Science 19: 11-18. [CrossRef] 
Morck, Randall, Daniel Wolfenzon, and Bernard Yeung. 2005. Corporate governance, economic entrenchment, and growth. Journal of Economic Literature 43: 655-720. [CrossRef]

Myers, Stewart C., and Nicholas S. Majluf. 1984. Corporate financing and investment decisions when firms have information that investors do not have. Journal of Financial Economics 13: 187-221. [CrossRef]

Nguyen Thanh, Cuong. 2019. Optimal Cash Holding Ratio for Non-Financial Firms in Vietnam Stock Exchange Market. Journal of Risk and Financial Management 12: 104. [CrossRef]

Nofsinger, John R., and Weicheng Wang. 2011. Determinants of start-up firm external financing worldwide. Journal of Banking $\mathcal{E}$ Finance 35: 2282-94.

Opler, Tim, Lee Pinkowitz, René Stulz, and Rohan Williamson. 1999. The determinants and implications of corporate cash holdings. Journal of Financial Economics 52: 3-46. [CrossRef]

Orr, Carrol A., and Samuel J. Miller. 1966. Anti-Wrinkle Cycle for Dryers. U.S. Patent No. 3,286,359, November 22.

Ozkan, Aydin, and Neslihan Ozkan. 2004. Corporate cash holdings: An empirical investigation of UK companies. Journal of Banking $\mathcal{E}$ Finance 28: 2103-34.

Pikulina, Elena, Luc Renneboog, and Philippe N. Tobler. 2017. Overconfidence and investment: An experimental approach. Journal of Corporate Finance 43: 175-92. [CrossRef]

Pinkowitz, Lee, René M. Stulz, and Rohan Williamson. 2004. Do Firms in Countries with Poor Protection of Investor Rights Hold More Cash? Cambridge: National Bureau of Economic Research.

Purhanudin, Noorfaiz, and Zuriawati Zakaria. 2015. Managerial Overconfidence and Debt Maturity Structure of Malaysian Construction and Material Companies. Review of Contemporary Business Research 1: 32-39. [CrossRef]

Puri, Manju, and David T. Robinson. 2007. Optimism and economic choice. Journal of Financial Economics 86: 71-99. [CrossRef]

Stephens, Christopher R., Harald A. Benink, Jose Luis Gordillo, and Juan Pablo Pardo-Guerra. 2007. A new measure of market inefficiency. Journal of Risk and Financial Management 14: 2-22. [CrossRef]

$\mathrm{Su}$, Xin, Shengshi Zhou, Rui Xue, and Jinfang Tian. 2020. Does economic policy uncertainty raise corporate precautionary cash holdings? Evidence from China. Accounting \& Finance 60: 4567-92.

Subramaniam, Venkat, Tony T. Tang, Heng Yue, and Xin Zhou. 2011. Firm structure and corporate cash holdings. Journal of Corporate Finance 17: 759-73. [CrossRef]

Tran, Ly Thi Hai, Thoa Thi Kim Tu, and Thao Thi Phuong Hoang. 2020. Managerial optimism and corporate cash holdings. International Journal of Managerial Finance 17: 214-36. [CrossRef]

Vijayakumaran, Ratnam. 2017. Capital structure decisions and corporate performance: Evidence from Chinese listed industrial firms. International Journal of Accounting and Financial Reporting 7: 562-76. [CrossRef]

Wang, Kun, Yaozhi Chen, Yao Liu, and Yingkai Tang. 2020. Board secretary's financial experience, overconfidence, and SMEs' financing preference: Evidence from China's NEEQ market. Journal of Small Business Management, 1-33. [CrossRef]

Whited, Toni M. 1992. Debt, liquidity constraints, and corporate investment: Evidence from panel data. The Journal of Finance 47: 1425-60. [CrossRef]

Whited, Toni M., and Guojun Wu. 2006. Financial constraints risk. The Review of Financial Studies 19: 531-59. [CrossRef]

Zhu, Jigao, and Zhengfei Lu. 2009. Monetary Policies, Enterprise'Growth, and the Change in the Level of Cash-holding. Management World 3: 152-58. 